\title{
Bahan Pakan Alternatif Sumber Energi untuk Subtitusi Jagung pada Unggas (Ulasan)
}

\section{Alternative Energy Source Feed Ingredients for Corn Substitution in Poultry (Review)}

\author{
D. N. Edi* \\ Seksi Pembibitan Ternak dan Hijauan Makanan Ternak \\ UPT Pembibitan Ternak dan Kesehatan Hewan, Madura \\ Dinas Peternakan Provinsi Jawa Timur, Pamekasan 69383, Jawa Timur, Indonesia \\ *Corresponding E-mail: didiknuredi@yahoo.co.id \\ (Diterima: 23 Oktober 2020; Disetujui: 20 Januari 2021)
}

\begin{abstract}
ABSTRAK
Tujuan dari ulasan ini adalah untuk memberikan gambaran tentang potensi bahan pakan alternatif sumber energi untuk substitusi jagung pada unggas. Ulasan ini membahas kandungan nutrien, rekomendasi batasan penggunaan dan dampak penggunaan bahan pakan alternatif terhadap produktifitas unggas. Bahan pakan alternatif yang dapat digunakan diantaranya adalah sorgum, gandum, jewawut, gaplek, tepung kentang, onggok, bungkil sawit, tepung kulit pisang, solid heavy phase, menir beras, mie afkir, dan roti afkir. Penggunaan bahan pakan alternatif harus memperhatikan batasan penggunaan, jenis unggas dan umur unggas. Selain itu, penggunaan bahan pakan alternatif juga harus diformulasikan dengan memperhatikan keseimbangan nutrien utama yaitu energi metabolis, protein kasar, serat kasar, lemak kasar, asam amino pembatas, kalsium, fosfor, dan densitas pakan. Penggunaan bahan pakan alternatif sesuai batasan penggunaan dapat menekan harga pakan, produktifitas ternak unggas tetap optimal, dan meningkatkan profitabiltas peternak.
\end{abstract}

Kata kunci: bahan pakan alternatif, batasan penggunaan, energi, jagung, substitusi

\section{ABSTRACT}

This review aimed to provide an overview of the potency of alternative energy source feed ingredients for corn substitution in poultry. This review discussed nutrient contents, recommended upper limit of usage, and the effect of using alternative feed ingredients on poultry productivity. Alternative feed ingredients that can be used included sorghum, wheat, foxtail millet, dried cassava, potato flour, cassava waste, palm kernel meal, banana peel flour, solid heavy phase, broken rice, noodle waste, and bread waste. The use of alternative feed ingredients should recognize the upper limit of usage, types of poultry, and birds' age. Besides, alternative feed ingredients should be formulated by considering the balance of primary nutrients such as metabolizable energy, crude protein, crude fiber, crude fat, limiting amino acids, calcium, phosphorus, and feed density. The use of alternative feed ingredients according to the upper limits of usage could reduce feed prices, keep optimum poultry productivity, and increase farmer profitability.

Keywords: alternative feed ingredients, corn, energy, substitution, upper limits of usage

\section{PENDAHULUAN}

Bahan baku pakan sumber energi pada pakan unggas banyak menggunakan jagung yaitu sekitar $50-55 \%$ dari total bahan pakan (Okereke, 2011). Jagung merupakan sumber energi utama pada unggas dan menyumbangkan lebih dari $70 \%$ dari kebutuhan energi metabolis pada unggas dan sisanya berasal dari bahan pakan sumber protein dan nutrien lainnya (Sultana et al., 2016). Jagung merupakan komoditas utama pertanian setelah beras/padi. Tiga Provinsi utama penghasil jagung di Indonesia adalah Jawa Timur 25,60\%, Jawa Tengah $14,11 \%$ dan Lampung $8,29 \%$ dari total produksi nasional 
(Pusat Data dan Sistem Informasi Pertanian Kementan RI, 2018).

Jagung merupakan sumber pangan fungsional dengan empat peran yaitu untuk pangan (food), pakan (feed), bahan bakar indutri (fuel), bahan baku industri (fiber) dan diperkirakan sekitar 58\% kebutuhan jagung dalam negeri dimanfaatkan untuk pakan, 30\% untuk pangan, sisanya untuk industri dan pembenihan (Panikkai et al., 2017). Menurut Kaul et al. (2019) secara global 63\% jagung digunakan untuk bahan pakan ternak utama, sisanya digunakan untuk sumber minyak, pati dan bahan bakar.

Permintaan jagung setiap tahun mengalami kenaikan seiring dengan pertambahan populasi ternak (Sinurat et al., 2007), karena merupakan salah satu komoditas utama dalam indutri pakan (Nafiah, 2009). Berdasarkan data dari Pusat Data dan Sistem Informasi Kementan RI (2018) melaporkan bahwa kebutuhan jagung nasional pada tahun 2018 untuk bahan baku pakan ternak mandiri 4,83 juta ton dan 8,30 juta ton untuk industri pakan, diproyeksikan meningkat menjadi 5,12 juta ton (pakan ternak mandiri) dan 9,75 juta ton (industri pakan ternak) pada tahun 2020. Mengurangi sebagian penggunaan jagung dalam formulasi pakan unggas dengan mensubtitusi dengan bahan pakan alternatif merupakan salah satu solusi untuk mengurangi kebutuhan jagung untuk pakan.

Bahan pakan alternatif yang memungkinkan untuk menggantikan jagung adalah bahan pakan yang mempunyai nutrien hampir setara dengan jagung. Menurut Sinurat et al. (2007), salah satu solusi untuk mengurangi penggunaan jagung untuk pakan adalah dengan memanfaatkan bahan baku lokal terutama hasil samping pertanian. Menurut Kasapidou et al. (2015) hasil samping agroindustri pertanian sekitar $30 \%$ nya potensial digunakan untuk pakan dan dapat mengurangi produk samping yang terbuang sehingga akan menciptakan integrasi pertanian dengan peternakan yaitu produk samping dari satu komponen berfungsi sebagai sumber daya untuk komponen lainnya "zero waste". Pemakaian produk samping agroindustri berperan untuk mengatasi masalah dalam pencemaran lingkungan (Kiramang, 2011).

Artikel ini akan mengkaji bahan baku alternatif sumber energi untuk subtitusi jagung pada unggas. Bahan baku tersebut merupakan hasil penelitian yang telah direkomendasikan sebagai bahan pakan alternatif sumber energi, untuk mensubtitusi jagung pada ternak unggas. Kajian ini berupa karakteristik nutrien, rekomendasi batasan penggunaan dan dampak pada produktifitas unggas.

\section{PEMBAHASAN}

\section{Karakteristik Nutrien Bahan Baku Sumber Energi}

Bahan baku alternatif untuk mengganti sebagian ataupun seluruhnya dari jagung harus memiliki beberapa syarat utama sebagai bahan baku sumber energi unggas. Menurut Hartadi (1980) beberapa syarat bahan baku sumber enargi adalah kandungan protein kasar (PK) kurang dari 20\%, serat kasar (SK) kurang dari 18\%, kandungan dinding sel (ADF) kurang dari 35\%. Pada dasarnya unggas sebagian besar sumber energi metabolis berasal dari pati (karbohidrat sederhana), dengan serat kasar rendah, palatabilitas tinggi karena secara anatomis dan fisiologi sistem pencernaan unggas sederhana sehingga sulit mencerna sumber energi dari karbohidrat komplek (selulosa dan hemiselulosa) (Sultana et al., 2016; Teme et al., 2019).

Karakteristik nutrienuntuk mensubtitusi jagung dikondisikan memiliki karakteristik nutrien yang mirip dengan jagung dengan cara pengolahan untuk meningkatkan nutrisi (misal fermentasi, pelleting, pemanasan) atau dengan penambahan imbuhan pakan (misal enzim, fitobiotik, zat warna sintetis). Hasil kajian kepustakaan bahan baku alternatif untuk subtitusi jagung dapat berasal dari hasil utama produk pertanian (sorgum, gandum, jewawut, gaplek dan kentang), hasil samping produk pertanian dan perkebunan (onggok, 
Tabel 1. Kandungan nutrien jagung dan bahan baku alternatif sumber energi.

\begin{tabular}{|c|c|c|c|c|c|c|c|c|c|}
\hline Bahan baku & $\begin{array}{c}\mathrm{BK} \\
(\mathrm{g} / \mathrm{kg})\end{array}$ & $\begin{array}{l}\mathrm{Abu} \\
(\mathrm{g} / \mathrm{kg})\end{array}$ & $\begin{array}{l}\mathrm{PK} \\
(\mathrm{g} / \mathrm{kg})\end{array}$ & $\begin{array}{c}\mathrm{SK} \\
(\mathrm{g} / \mathrm{kg})\end{array}$ & $\begin{array}{l}\mathrm{LK} \\
(\mathrm{g} / \mathrm{kg})\end{array}$ & $\begin{array}{c}\mathrm{KH} \\
(\mathrm{g} / \mathrm{kg})\end{array}$ & $\begin{array}{l}\text { Pati } \\
(\mathrm{g} / \mathrm{kg})\end{array}$ & $\underset{(\mathrm{kkal} / \mathrm{kg})}{\mathrm{EM}}$ & Sumber \\
\hline Jagung & 872 & 14 & 81 & 26 & 40 & 753 & 610 & 3356 & $\begin{array}{l}\text { Kumaravel and } \\
\text { Natarajan, 2015; } \\
\text { Weurding et al., } 2001\end{array}$ \\
\hline Sorgum & 856 & 14 & 78 & 25 & 30 & 730 & 616 & 3320 & $\begin{array}{l}\text { Nopriani, 2006; } \\
\text { Weurding et al., } 2001\end{array}$ \\
\hline Gandum & 873 & 16 & 115 & 29 & 15 & 753 & 739 & 2985 & $\begin{array}{l}\text { Octavia et al., 2018; } \\
\text { Kumar et al., 2011; } \\
\text { Weurding et al., } 2001\end{array}$ \\
\hline Jewawut & 905 & 35 & 103 & 71 & 65 & 747 & 639 & 3075 & $\begin{array}{l}\text { Goodarzi Boroojeni et } \\
\text { al., 2011; Kumaraveol } \\
\text { and Natarajan, } 2015\end{array}$ \\
\hline Gaplek & 886 & 61 & 23 & 48 & 4 & 751 & 617 & 2970 & $\begin{array}{l}\text { Weurding et al., 2001; } \\
\text { Mampioper et al., 2008; } \\
\text { Bhuiyan and Iji, } 2015\end{array}$ \\
\hline $\begin{array}{l}\text { Tepung } \\
\text { kentang }\end{array}$ & 942 & 27,1 & 86 & 21 & 9,8 & - & 774 & 3345 & $\begin{array}{l}\text { Adami et al., 2017; } \\
\text { Mampioper } \text { et al., } 2008\end{array}$ \\
\hline Onggok & 826 & 15,4 & 17 & 148 & 7,9 & 670 & 465 & 2783 & Edi, 2010; Musita, 2018 \\
\hline $\begin{array}{l}\text { Bungkil } \\
\text { sawit }\end{array}$ & 940 & 3 & 140 & 206 & 97 & 524 & 420 & 2690 & $\begin{array}{l}\text { Edi, 2010; Sundu et al., } \\
2006\end{array}$ \\
\hline SHP & 924 & 127 & 100 & 214 & 151 & - & - & $3080 *$ & Sinurat et al., 2007 \\
\hline $\begin{array}{l}\text { Kulit } \\
\text { pisang }\end{array}$ & 147 & 156 & 52 & 123 & 155 & - & 590 & 2864 & $\begin{array}{l}\text { Putra dan Sudarwati, } \\
\text { 2019; Fitroh et al., } 2018\end{array}$ \\
\hline $\begin{array}{l}\text { Kulit } \\
\text { pisang } \\
\text { fermentasi }\end{array}$ & 194 & 115 & 63 & 152 & 83 & - & - & 2805 & $\begin{array}{l}\text { Hudiansyah et al., 2015; } \\
\text { Putra dan Sudarwati, } \\
2019\end{array}$ \\
\hline $\begin{array}{l}\text { Menir } \\
\text { beras }\end{array}$ & 894 & 6,2 & 81 & 5 & 6 & - & 802 & 3090 & $\begin{array}{l}\text { Ashour et al., 2016; } \\
\text { Astuti, } 2009\end{array}$ \\
\hline Mie afkir & 943 & 21,6 & 116 & 6,5 & 182 & 731 & - & 3650 & $\begin{array}{l}\text { Widodo et al., 2010; } \\
\text { Marsono dan Astanu, } \\
2002\end{array}$ \\
\hline Roti afkir & 930 & 8 & 102 & 120 & 134 & 566 & - & $2952 *$ & Kusmayadi, 2019 \\
\hline
\end{tabular}

Keterangan: BK (bahan baku), PK (protein kasar), SK (serat kasar), LK (lemak kasar), KH (karbohidrat), EM (energi metabolis), GE (gross energi); ${ }^{*} \mathrm{EM}=70 \% \mathrm{GE}$ (Schaible, 1979 disitasi oleh Edi, 2010)

bungkil sawit, kulit pisang, solid heavy phase (SHP)) dan produk afkir industri (menir beras, mie afkir, roti afkir). Kandungan nutrien bahan baku alternatif sumber energi dibandingkan dengan jagung ditampilkan pada Tabel 1.

Pakan sumber energi menempati porsi sekitar $50-60 \%$ pada formulasi pakan unggas sehingga rata-rata menyumbangkan protein sekitar $5 \mathrm{~g} / \mathrm{kg}$ pakan atau sekitar 30\% dari kebutuhan protein unggas dengan asumsi rataan kandungan protein bahan baku sumber energi $81 \mathrm{~g} / \mathrm{Kg}$ (Tabel 1) dan kebutuhan protein unggas sekitar $17 \mathrm{~g} / \mathrm{ek} / \mathrm{hari}$ (Riberio et al., 2016). Sumbangan protein dari bahan baku sumber energi pada unggas cukup tinggi sehingga kandungan tentang profil asam amino pada bahan baku sumber energi alternatif perlu dikaji. Samadi (2012) menyatakan bahwa kandungan asam amino esensial yang tidak tepat baik kelebihan ataupun kekurangan akan 
JPI Vol. 23 (1): 43-61

Tabel 2. Kandungan asam amino dan makro mineral pada bahan baku alternatif sumber energi.

\begin{tabular}{|c|c|c|c|c|c|c|c|c|c|}
\hline Bahan baku & $\begin{array}{l}\text { Lis } \\
(\%)\end{array}$ & $\begin{array}{l}\text { Met } \\
(\%)\end{array}$ & $\begin{array}{l}\text { Tre } \\
(\%)\end{array}$ & $\begin{array}{l}\text { Trip } \\
(\%)\end{array}$ & $\begin{array}{l}\text { Sis } \\
(\%)\end{array}$ & $\begin{array}{l}\text { Arg } \\
(\%)\end{array}$ & $\begin{array}{l}\mathrm{Ca} \\
(\%)\end{array}$ & $\mathrm{P}(\%)$ & Sumber \\
\hline Jagung & 0,23 & 0,16 & 0,27 & 0,06 & 0,17 & 0,36 & 0,01 & 0,28 & Hy-line, 2014 \\
\hline Sorgum & 0,25 & 0,19 & 0,35 & 0,12 & 0,19 & 0,41 & 0,04 & 0,29 & Hy-line, 2014 \\
\hline Gandum & 0,31 & 0,17 & 0,31 & 0,14 & 0,25 & 0,52 & 0,05 & 0,30 & Hy-line, 2014 \\
\hline Jewawut & 0,34 & 0,25 & 0,52 & 0,26 & 0,23 & 0,79 & 0,05 & 0,43 & Singh, 2004) \\
\hline Gaplek & 0,08 & 0,02 & 0,06 & - & - & 0,08 & 0,28 & 0,07 & Bhuiyan and Iji, 2015 \\
\hline $\begin{array}{l}\text { Tepung } \\
\text { kentang }\end{array}$ & 1,30 & - & 2,90 & - & 1,00 & 0,40 & 0,02 & 0,27 & $\begin{array}{l}\text { Adami et al., 2017; Hur } \\
\text { et al., } 2011\end{array}$ \\
\hline Onggok & 0,03 & - & 0,01 & 0,02 & 0,01 & 0,04 & 0,09 & 0,04 & $\begin{array}{l}\text { Edi, 2010; Aro and } \\
\text { Aletor, 2012 }\end{array}$ \\
\hline Bungkil sawit & 0,59 & 0,30 & 0,55 & 0,17 & 0,2 & 2,18 & 0,36 & 0,71 & $\begin{array}{l}\text { Sundu et al., 2006; Edi, } \\
2010\end{array}$ \\
\hline SHP & 0,13 & 0,19 & 0,48 & 0,40 & - & 0,39 & 0,47 & 0,18 & Sinurat et al., 2007 \\
\hline Kulit pisang & - & - & - & - & - & - & 0,27 & 0,26 & Fitroh et al., 2018 \\
\hline $\begin{array}{l}\text { Kulit pisang } \\
\text { fermentasi }\end{array}$ & 0,25 & 0,04 & - & - & - & 0,21 & 0,86 & 0,41 & $\begin{array}{l}\text { Hudiansyah dan } \\
\text { Sunarti, } 2015\end{array}$ \\
\hline Menir beras & 0,27 & 0,15 & 0,21 & - & - & 0,65 & 0,01 & 0,07 & Chen et al., 2020 \\
\hline Mie afkir & 0,21 & 0,14 & 0,26 & - & - & 0,38 & 0,13 & 0,24 & Sukarman, 2011 \\
\hline
\end{tabular}

Keterangan: Lis (lisin), Met (metionin), Tre (treonin), Trip (tripsin), Sis (sistin), Arg (arginin), Ca (kalsium), $\mathrm{P}$ (fosfor).

mengakibatkan ketidakseimbangan asam amino dan antagonis. Kandungan asam amino dan mineral makro pada unggas disajikan pada Tabel 2.

Asam amino yang dijasikan pada Tabel 2 merupakan asam amino esensial dan beberapa diantaranya merupakan asam amino pembatas pada jagung. Asam amino pembatas pada jagung adalah lisin, metionin dan triptopan (Scott et al., 2006). Mineral yang terpenting dan merupakan pembatas dalam matabolisme pada unggas adalah kalsium dan fospor (Adedokun and Adeola, 2013) mineral kalsium dan fospor berfungsi untuk pembentukan tulang dan cangkang telur (Bangun, 2013).

Densitas merupakan karakteristik fisik kepadatan bahan baku. Secara umum densitas nutrien merupakan faktor penting yang memberikan pengaruh pada pertumbuhan, keseragaman, kesehatan dan ekonomi serta produktifitas ayam pedaging (Ismail et al., 2016). Densitas pakan rendah menyebabkan intake nutrien rendah bila dibandingkan dengan pakan yang mempunyai densitas tinggi, jika konsumsi sama. Densitas pakan erat kaitannya dengan bentuk pakan, densitas pakan rendah akan menyebabkan densitas nutrien rendah sehingga dapat menurunkan kualitas pakan dan performan unggas (Jafarnejad et al., 2010). Densitas bahan baku sumber energi ditampilkan pada Grafik 1.

Bahan baku alternatif yang mempunyai densitas menyerupai jagung adalah gandum, kentang dan menir beras yaitu diatas $700 \mathrm{Kg} / \mathrm{L}$ dan yang memiliki densitas antara 600-700 $\mathrm{Kg} / \mathrm{L}$ adalah jewawut, onggok, bungkil sawit, tepung kulit pisang, tepung mie afkir (Grafik 1). Bahan baku dengan densitas rendah $<600 \mathrm{Kg} / \mathrm{L}$, diperlukan peningkatan densitas dengan cara dibuat pellet atau crumbel (Ismail et al., 2016), seperti tepung gaplek dan tepung roti afkir atau biskuit. Bozkurt et al. (2019) menyebutkan perubahan fisik dan kimia selama prosesing pakan sangat berpengaruh pada performan ternak, terutama pada ayam 




Grafik 1. Densitas bahan baku pakan unggas sumber energi pada unggas (Sumber: Charrondiere et al., 2015; *Sundu et al., 2006; **Atapattu and Senevirathne, 2012)

pedaging yaitu berpengaruh pada kecernaan pakan, konsumsi serta kesehatan dan fungsi saluran pencernaan.

\section{Batasan Penggunaan}

Batasan penggunaan bahan baku alternatif sumber energi untuk subtitusi jagung bervariasi tergantung dari beberapa hal diantaranya adalah karakteristik nutrien bahan baku pakan, kandungan antinutrisi, perlakuan pendahuluan dan aplikasinya pada jenis unggas serta umur unggas. Level subtitusi jagung dengan bahan baku alternatif sumber energi pada unggas disajikan pada Tabel 3. Rekomendasi tersebut merupakan persen terhadap jagung bukan dalam formulasi pakan. Rekomendasi batasan penggunaan bahan baku alternatif ini merupakan level optimal dengan parameter produktifitas ternak dan profitabiltas peternak. Analisa ekonomi penggunaan jagung dibandingakan dengan subtitusi bahan baku alternatif dapat dilihat pada Tabel 4. Indikator profitabiltas peternak dapat dilihat dari nilai IOFC (Income Over Feed Cost), harga pakan dan total biaya produksi untuk menghasilkan per unit produk ternak unggas (daging, telur) (Kusmayadi, 2019; Medugu et al., 2010).

Karakteristik nutrien bahan baku alternatif yang mirip dengan jagung dapat mensubtitusi jagung lebih banyak dan sebaliknya. Bahan baku alternatif yang mengandung energi tinggi atau hampir sama dengan jagung dapat mensubtitusi jagung hingga $100 \%$, misalnya sorgum dan gandum (Tabel 3). Antinutrisi merupakan faktor pembatas kedua yang perlu diperhatikan karena dapat menurunkan kualitas bahan pakan dalam formulasi pakan unggas (Jayanegara et al., 2019). Antinutrisi pada bahan baku unggas sumber energi antara lain adalah tanin, HCN (Hydrogen cyanide), densitas rendah, serat kasar tinggi dan kandungan NSP (Non Starch Polysaccahride). Kandungan serat kasar dalam pakan dibutuhkan oleh ternak unggas pada level tertentu untuk efek toksikologi, efek prebiotik dan efesiensi pakan sebaliknya dalam jumlah yang terlalu tinggi dapat menurunkan kecernaan pakan (Has et al., 2014), sehingga dalam formulasi pakan dicari level optimalnya disesuaikan dengan jenis dan umur unggas.

Jenis dan umur unggas dapat mempengaruhi level subtitusi jagung dengan bahan baku alternatif karena setiap jenis unggas mempunyai karakteristik anatomi sistem pencernaan yang berbeda sehingga mempengaruhi proses pencernaan dan penyerapan nutrien pakan (Kierończyk et al., 
JPI Vol. 23 (1): 43-61

Tabel 3. Level subtitusi jagung dengan bahan baku alternatif sumber energi

\begin{tabular}{|c|c|c|c|c|}
\hline Bahan baku & Jenis unggas & $\begin{array}{c}\text { Subtitusi } \\
\text { Jagung (\%) }\end{array}$ & Perlakuan & Sumber \\
\hline \multirow[t]{5}{*}{ Sorghum } & Ayam petelur layer & 50 & - & Issa et al., 2016 \\
\hline & Ayam petelur layer & 100 & $\begin{array}{c}6 \% \text { tepung indigofera } \\
\text { dan probiotik }\left(43 \times 10^{12}\right. \\
\mathrm{CFU} / \mathrm{mL})\end{array}$ & $\begin{array}{l}\text { Sriagtula et al., } \\
2019\end{array}$ \\
\hline & Ayam pedaging finisher & 21 & - & Bulu et al., 2018 \\
\hline & Ayam pedaging stater & 100 & $\begin{array}{l}\text { Sorgum low tanin } \\
\text { (Sorghum bicolor } \\
\text { cultivar Faourou) }\end{array}$ & $\begin{array}{l}\text { Tandiang et al., } \\
2014\end{array}$ \\
\hline & Ayam pedaging finisher & 100 & $\begin{array}{l}\text { Sorgum low tanin } \\
\text { (Sorghum bicolor } \\
\text { cultivar Faourou) }\end{array}$ & $\begin{array}{l}\text { Tandiang et al., } \\
2014\end{array}$ \\
\hline \multirow[t]{3}{*}{ Gandum } & Ayam petelur layer & 100 & Enzim cocktail $(0,09 \%)$ & Zarei et al., 2011 \\
\hline & Ayam pedaging & 20 & $\begin{array}{c}\text { Penambahan enzim } \\
\text { xilanase (11000 unit/Kg } \\
\text { pakan) }\end{array}$ & $\begin{array}{l}\text { Octavia et al., } \\
2018\end{array}$ \\
\hline & Ayam pedaging & 50 & $\begin{array}{c}\text { Penambahan enzim } 200 \\
\text { g/ton (enzim amilase } \\
\text { dan protease) }\end{array}$ & $\begin{array}{l}\text { ElKatcha et al., } \\
2014\end{array}$ \\
\hline \multirow[t]{4}{*}{ Jewawut } & Ayam petelur layer & 42 & - & Cisse et al., 2017 \\
\hline & Ayam petelur & 50 & - & Issa et al., 2016 \\
\hline & Ayam pedaging & 42 & - & Cisse et al., 2017 \\
\hline & Ayam pedaging & 100 & - & $\begin{array}{l}\text { Goodarzi } \\
\text { Boroojeni et al., } \\
2011\end{array}$ \\
\hline \multirow[t]{9}{*}{ Gaplek } & Ayam petelur layer & 25 & - & $\begin{array}{l}\text { Anderemi et al., } \\
2012\end{array}$ \\
\hline & Ayam petelur layer & 30 & - & Okereke, 2011 \\
\hline & Ayam petelur layer & 45 & - & $\begin{array}{l}\text { Mampioper et al., } \\
2008\end{array}$ \\
\hline & Ayam pedaging stater & 30 & - & Okereke, 2011 \\
\hline & Ayam pedaging finisher & 35 & - & Okereke, 2011 \\
\hline & Ayam pedaging finisher & 46,5 & - & $\begin{array}{l}\text { Mampioper et al., } \\
2008\end{array}$ \\
\hline & Ayam pedaging stater & 51 & - & $\begin{array}{l}\text { Mampioper et al., } \\
2008\end{array}$ \\
\hline & Ayam pedaging & 100 & $\begin{array}{c}\text { Pellet dan penambahan } \\
\text { enzim (xylanase, } \\
\text { amylase, protease and } \\
\text { phytase) }\end{array}$ & $\begin{array}{l}\text { Bhuiyan and Iji, } \\
2015\end{array}$ \\
\hline & Puyuh petelur & 35 & - & Okereke, 2011 \\
\hline \multirow{3}{*}{$\begin{array}{l}\text { Tepung } \\
\text { kentang }\end{array}$} & Ayam petelur & 25 & - & Okereke, 2011 \\
\hline & Ayam petelur & 30 & - & Sultana et al., 2016 \\
\hline & Ayam petelur grower & 45 & - & Okereke, 2011 \\
\hline
\end{tabular}


JPI Vol. 23 (1): 43-61

\begin{tabular}{|c|c|c|c|c|}
\hline Bahan baku & Jenis unggas & $\begin{array}{c}\text { Subtitusi } \\
\text { Jagung (\%) }\end{array}$ & Perlakuan & Sumber \\
\hline & Ayam pedaging stater & 20 & - & Okereke, 2011 \\
\hline & Ayam pedaging & 30 & & Sultana et al., 2016 \\
\hline & Ayam pedaging & 40 & - & Adami et al., 2017 \\
\hline & Ayam pedaging finisher & 50 & - & Okereke, 2011 \\
\hline & Puyuh petelur & 38,7 & - & Okereke, 2011 \\
\hline \multirow[t]{8}{*}{ Onggok } & Ayam petelur layer & 10 & - & $\begin{array}{l}\text { Diarra dan Devi, } \\
2015\end{array}$ \\
\hline & Ayam petelur layer & 20 & $\begin{array}{c}\text { Penambahan metionin } \\
0,15-0,30 \%\end{array}$ & $\begin{array}{l}\text { Diarra dan Devi, } \\
2015\end{array}$ \\
\hline & Ayam petelur layer & 50 & - & $\begin{array}{l}\text { Oladunjoye et al., } \\
2010\end{array}$ \\
\hline & Ayam petelur layer & 70 & $\begin{array}{c}\text { Low } \mathrm{HCN} \text { (treatmen } \\
\text { lye) }\end{array}$ & $\begin{array}{l}\text { Oladunjoye et al., } \\
2010\end{array}$ \\
\hline & Ayam pedaging finisher & 10 & - & Babatunde, 2013 \\
\hline & Ayam pedaging & 15 & $\begin{array}{c}\text { Penambahan metionin } \\
0,15-0,30 \%\end{array}$ & $\begin{array}{l}\text { Diarra dan Devi, } \\
2015\end{array}$ \\
\hline & Ayam pedaging & 20 & - & $\begin{array}{l}\text { Ali-Mursyid et al., } \\
2010\end{array}$ \\
\hline & Ayam pedaging & 30 & Fermentasi & $\begin{array}{l}\text { Ali-Mursyid et al., } \\
2010\end{array}$ \\
\hline \multirow{9}{*}{$\begin{array}{l}\text { Bungkil } \\
\text { sawit }\end{array}$} & Ayam petelur layer & 10 & - & Zanu et al., 2012 \\
\hline & Ayam petelur layer & 12,5 & $\begin{array}{l}\text { Penambahan } \\
\text { enzim (mannanase, } \\
\alpha \text {-galactosidase and } \\
\text { protease) } 1 \mathrm{~kg} / \mathrm{ton}\end{array}$ & Chong et al., 2008 \\
\hline & Ayam petelur layer & 25 & $\begin{array}{c}\text { Penambahan } \\
\text { enzim (mannanase, } \\
\alpha \text {-galactosidase and } \\
\text { protease) } 2 \mathrm{~kg} / \mathrm{ton}\end{array}$ & Chong et al., 2008 \\
\hline & Ayam pedaging & 10 & $\begin{array}{l}\text { Penambahan enzim } \\
\text { (amylase, hemicellulase, } \\
\text { cellulose, protease dan } \\
\text { betaglucanase) } 0,05 \%\end{array}$ & Shakila et al., 2012 \\
\hline & Ayam pedaging & 12,5 & - & Natsir et al., 2018 \\
\hline & Ayam pedaging & 15 & Fermentasi & $\begin{array}{l}\text { Alshelmani et al., } \\
2016\end{array}$ \\
\hline & Ayam pedaging & 25 & $\begin{array}{l}\text { Penambahan enzim } \\
\text { mannase }\end{array}$ & Natsir et al., 2018 \\
\hline & Ayam pedaging & 40 & $\begin{array}{l}\text { Penambahan asam } \\
\text { amino dan enzim }\end{array}$ & Sundu et al., 2006 \\
\hline & Itik petelur & 50 & - & $\begin{array}{l}\text { Onunkwo et al., } \\
2018\end{array}$ \\
\hline SHP & Ayam petelur fase layer & 25 & Dikeringkan & Sinurat et al., 2007 \\
\hline
\end{tabular}




\begin{tabular}{|c|c|c|c|c|}
\hline Bahan baku & Jenis unggas & $\begin{array}{c}\text { Subtitusi } \\
\text { Jagung (\%) }\end{array}$ & Perlakuan & Sumber \\
\hline \multirow[t]{4}{*}{$\begin{array}{l}\text { Kulit } \\
\text { pisang }\end{array}$} & Ayam pedaging & 5 & Fermentasi & $\begin{array}{l}\text { Hudiansyah et al., } \\
2015\end{array}$ \\
\hline & Ayam pedaging & 10 & Tepung & Fas et al., 2015 \\
\hline & Ayam pedaging finisher & 30 & Perebusan & $\begin{array}{l}\text { Atapattu and } \\
\text { Senevirathne, } 2012\end{array}$ \\
\hline & Itik pedaging & 25 & Tepung & Fitroh et al., 2018 \\
\hline \multirow{7}{*}{$\begin{array}{l}\text { Menir } \\
\text { beras }\end{array}$} & Ayam petelur layer & 50 & - & Jadhao et al., 2000 \\
\hline & Ayam petelur layer & 100 & - & Sittiya et al., 2014 \\
\hline & Ayam pedaging & 25 & - & $\begin{array}{l}\text { Almrsomi et al., } \\
2019\end{array}$ \\
\hline & Ayam pedaging & 40 & - & Mir et al., 2017 \\
\hline & Puyuh petelur & 15 & - & Ashour et al., 2016 \\
\hline & Puyuh & 20 & Penambahan enzim & Attia et al., 2006 \\
\hline & $\begin{array}{l}\text { Puyuh } \\
\text { Angsa }\end{array}$ & $\begin{array}{c}100 \\
75\end{array}$ & $\begin{array}{l}- \\
-\end{array}$ & $\begin{array}{l}\text { Filgueira et al., } \\
2014 \\
\text { Chen } \text { et al., } 2020\end{array}$ \\
\hline Mie afkir & Ayam pedaging & 20 & - & $\begin{array}{l}\text { Widodo et al., } \\
2010\end{array}$ \\
\hline \multirow[t]{2}{*}{ Roti afkir } & Itik pedaging & 10 & $\begin{array}{l}\text { Penambahan tepung } \\
\text { kulit manggis } 2 \%\end{array}$ & Kusmayadi, 2019 \\
\hline & Itik pedaging & 100 & $\begin{array}{c}\text { Penambahan tepung } \\
\text { jerami bawang putih } \\
20 \%\end{array}$ & $\begin{array}{l}\text { Trisnadewi et al., } \\
2012\end{array}$ \\
\hline
\end{tabular}

2016). Umur unggas akan mempengaruhi perkembangan sistem pencernaan, kebutuhan nutrien pakan dan produktifitas ternak unggas.

Unggas semakin tua mempunyai kecenderungan level subtitusi bahan baku alternatif terhadap jagung semakin tinggi begitu juga dengan unggas lokal (itik, angsa, buras) mempunyai kecenderungan lebih tinggi level subtitusinya. Hal ini dapat terjadi karena seiring dengan bertambahnya umur unggas sistem pencernaan semakin sempurna dan pada unggas lokal (ayam buras) secara fisiologi dan anatomi sedikit berbeda dengan ayam ras (Rahmawati, 2016) karena jenis pakannya berbeda. Aqsa et al. (2016) menambahkan bentuk fisik pakan akan mempengaruhi fisiologis sistem pencernaan, misalnya ukuran gizzard mudah berubah bergantung pada jenis pakan yang biasa dimakan oleh unggas tersebut.

Perlakuan pendahuluan juga akan mempengaruhi level subtitusi jagung dengan bahan baku alternatif. Bahan baku yang melalui proses perlakuan terlebih dahulu dapat mensubtitusi jagung lebih tinggi dari pada tanpa perlakuan (Tabel 3). Hal ini dapat terjadi karena dengan perlakuan antinutrisi dan densitas sebagai pembatas dapat dikurangi. Perlakuan untuk meningkatkan kandungan nutrien bahan pakan dapat dilakukan diantaranya dengan fermentasi, penambahan probiotik dan penambahan imbuhan pakan (Aqsa et al., 2016; Sinurat et al., 2007).

\section{Dampak pada Produktifitas Ternak Unggas}

Subtitusi jagung dengan bahan baku alternatif mempunyai pengaruh negatif bila berlebihan maupun dapat sama bahkan lebih baik dari pada jagung pada taraf tertentu. 
Tabel 4. Analisa ekonomi penggunaan jagung dibandingakan dengan subtitusi bahan baku alternatif

\begin{tabular}{|c|c|c|c|c|c|c|}
\hline Bahan baku & $\begin{array}{l}\text { Jenis } \\
\text { unggas }\end{array}$ & $\begin{array}{c}\text { Parameter } \\
\text { ekonomi }\end{array}$ & $\begin{array}{c}\text { Level } \\
\text { subtitusi }\end{array}$ & Kontrol & Perlakuan & Sumber \\
\hline Sorgum & $\begin{array}{l}\text { Ayam } \\
\text { pedaging }\end{array}$ & $\begin{array}{l}\text { Harga } \\
\text { pakan }\end{array}$ & 100 & $52,2 \mathrm{NGN} / \mathrm{kg}$ & $46,8 \mathrm{NGN} / \mathrm{kg}$ & $\begin{array}{l}\text { Medugu et al., } \\
2010\end{array}$ \\
\hline Jewawut & $\begin{array}{l}\text { Ayam } \\
\text { pedaging }\end{array}$ & $\begin{array}{l}\text { Harga } \\
\text { pakan }\end{array}$ & 100 & $52,2 \mathrm{NGN} / \mathrm{kg}$ & $41,2 \mathrm{NGN} / \mathrm{kg}$ & $\begin{array}{l}\text { Medugu et al., } \\
2010\end{array}$ \\
\hline Gaplek & $\begin{array}{l}\text { Ayam } \\
\text { pedaging }\end{array}$ & $\begin{array}{l}\text { Total biaya } \\
\text { pakan }\end{array}$ & 25 & 3480 NGN/ek & 3080 NGN/ek & $\begin{array}{l}\text { Anaeto and } \\
\text { Adighibe, } 2011\end{array}$ \\
\hline Onggok & $\begin{array}{l}\text { Ayam } \\
\text { petelur }\end{array}$ & $\begin{array}{l}\text { Harga } \\
\text { pakan }\end{array}$ & 50 & $53,5 \mathrm{NGN} / \mathrm{kg}$ & $50,9 \mathrm{NGN} / \mathrm{kg}$ & $\begin{array}{l}\text { Oladunjoye et } \\
\text { al., } 2010\end{array}$ \\
\hline $\begin{array}{l}\text { Bungkil } \\
\text { sawit }\end{array}$ & $\begin{array}{l}\text { Ayam } \\
\text { pedaging }\end{array}$ & IOFC & 12,5 & $18461 \mathrm{IDR} / \mathrm{ek}$ & 18975 IDR/ek & $\begin{array}{l}\text { Natsir et al., } \\
2018\end{array}$ \\
\hline Kulit pisang & $\begin{array}{l}\text { Ayam } \\
\text { pedaging }\end{array}$ & $\begin{array}{l}\text { Harga } \\
\text { pakan }\end{array}$ & 10 & $\begin{array}{c}105,54 \mathrm{NGN} / \\
\mathrm{kg}\end{array}$ & $\begin{array}{c}100,42 \mathrm{NGN} / \\
\mathrm{kg}\end{array}$ & Fas et al., 2015 \\
\hline Menir beras & $\begin{array}{l}\text { Ayam } \\
\text { petelur }\end{array}$ & $\begin{array}{l}\text { Harga } \\
\text { pakan }\end{array}$ & 50 & 5,67 INR/kg & $5,17 \mathrm{INR} / \mathrm{kg}$ & $\begin{array}{l}\text { Jadhao et al., } \\
2000\end{array}$ \\
\hline Roti afkir & Itik & IOFC & 10 & 11486 IDR/ek & 11465 IDR/ek & $\begin{array}{l}\text { Kusmayadi, } \\
2019\end{array}$ \\
\hline
\end{tabular}

Keterangan: NGN (naira), INR (Rupee), IDR (Rupiah), ek (ekor), kg (kilogram), IOFC (income over feed cost)

Dampak biologis yang diulas dalam artikel ini terbagi dua, yaitu pengaruh terhadap produksi dan kualitas. Pengaruh bahan baku alternatif sumber energi tanpa perlakuan terhadap performan unggas ditampilkan pada Tabel 5, 6 dan 7.

Sorgum pada ayam petelur dan ayam pedaging dapat menggantikan jagung hingga $100 \%$ dengan indikator produksinya sama (Tabel 5 dan Tabel 7). Sorgum dapat menggantikan jagung karena dari segi nutrien mirip dengan jagung (Tabel 1) tetapi untuk dapat menggantikan jagung $100 \%$ harus dilakukan beberapa perlakuan untuk mengurangi antinutrisi pada sorgum. Kandungan antinutrisi pada sorgum adalah tanin 3,67-10,66\% tergantung varietasnya dan asam fitat 19,53 $\mathrm{mg} / \mathrm{g}$ (Setiarto dan Widhyastuti, 2016). Perlakuan untuk mengurangi tanin dapat dikakukan dengan menambah $6 \%$ tepung indigofera dan probiotik sebanyak $43 \times 10^{12} \mathrm{CFU} / \mathrm{mL}$ (Sriagtula et al., 2019), penambahan $0,15-0,30 \%$ metionin atau cholin (Issa, 2009), fermentasi dengan $R$. oligosporus, L. plantarum dan S. Cerevisiae (Setiarto dan Widhyastuti, 2016).

Pemanfaatan tepung gandum untuk subtitusi jagung mempunyai kendala diantaranya adalah kandungan NSP tinggi. Permasalahan tersebut dapat dikurangi dengan penambahan enzim (ElKatcha et al., 2014) sehingga dari laporan penelitian (Zarei et al., 2011) pada ayam petelur gandum dapat menggantikan jagung hingga $100 \%$ dengan penambahan enzim cocktail sebanyak 0,09\% campuran pakan dengan indikator produksi telur.

Jewawut dapat menggantikan jagung hingga 50\% tanpa pengaruh negatif terhadap produksi dan kualitas telur pada ayam petelur. Kendala penggunaan jewawut adalah serat kasar tinggi sehingga diperlukan perlakuan misalnya fermentasi, penambahan enzim, probiotik, untuk mengurangi dampak negatifnya. Menurut Boroojeni et al. (2011) tepung jewawut dapat menggantikan jagung hingga $100 \%$ tanpa pengaruh negatif dengan 
JPI Vol. 23 (1): 43-61

Tabel 5. Pengaruh subtitusi jagung dengan bahan baku alternatif terhadap produksi ayam petelur

\begin{tabular}{|c|c|c|c|c|c|c|c|c|c|}
\hline $\begin{array}{l}\text { Bahan } \\
\text { pakan } \\
\text { alternatif }\end{array}$ & Umur & Strain & Subtitusi & HDP & MT & Kon & BT & FCR & Sumber \\
\hline \multirow[t]{2}{*}{ Sorgum } & \multirow[t]{2}{*}{30} & \multirow[t]{2}{*}{ Isa Brown } & kontrol & 83,2 & 48,8 & 121,8 & 63,8 & 2,5 & \multirow{2}{*}{$\begin{array}{l}\text { Sriagtula et al., } \\
2019\end{array}$} \\
\hline & & & 100 & 84,5 & 49,3 & 121,4 & 62,3 & 2,4 & \\
\hline \multirow[t]{2}{*}{ Jewawut } & \multirow[t]{2}{*}{31} & \multirow[t]{2}{*}{ Harco line } & kontrol & 83,8 & - & 112,0 & 49 & 1,6 & \multirow[t]{2}{*}{ Issa et al., 2016} \\
\hline & & & 50 & 84,4 & - & 106,0 & 48 & 1,6 & \\
\hline \multirow[t]{2}{*}{ Gaplek } & \multirow[t]{2}{*}{24} & \multirow{2}{*}{$\begin{array}{l}\text { Petelur } \\
\text { hitam }\end{array}$} & kontrol & 87,9 & - & 109,0 & 60,2 & - & \multirow{2}{*}{$\begin{array}{l}\text { Anaeto and } \\
\text { Adighibe, } 2011\end{array}$} \\
\hline & & & 25 & 85,7 & - & 101,9 & 60,9 & - & \\
\hline \multirow{2}{*}{$\begin{array}{l}\text { Tepung } \\
\text { kentang }\end{array}$} & \multirow[t]{2}{*}{30} & - & kontrol & 57,0 & 48,1 & 105,1 & 40,1 & 2,2 & \multirow{2}{*}{$\begin{array}{l}\text { Sultana et al., } \\
2016\end{array}$} \\
\hline & & - & 30 & 52,9 & 46,1 & 105,0 & 39,0 & 2,3 & \\
\hline \multirow[t]{2}{*}{ Onggok } & \multirow[t]{2}{*}{22} & \multirow[t]{2}{*}{ Harco } & kontrol & 71,0 & - & 122,4 & 56,2 & 2,7 & \multirow{2}{*}{$\begin{array}{l}\text { Oladunjoye } e t \\
\text { al., } 2010\end{array}$} \\
\hline & & & 50 & 70,0 & - & 123,2 & 57,1 & 2,7 & \\
\hline \multirow{2}{*}{$\begin{array}{l}\text { Bungkil } \\
\text { sawit }\end{array}$} & \multirow[t]{2}{*}{40} & \multirow{2}{*}{$\begin{array}{l}\text { Lohman } \\
\text { Brown }\end{array}$} & kontrol & 77,0 & 26,7 & 136,3 & 64,7 & - & \multirow[t]{2}{*}{ Zanu et al., 2012} \\
\hline & & & 10 & 81,0 & 29,7 & 136,7 & 68,5 & - & \\
\hline \multirow[t]{2}{*}{ SHP } & \multirow[t]{2}{*}{17} & \multirow[t]{2}{*}{ Isa Brown } & kontrol & 79,3 & - & 110,1 & 60,7 & 2,5 & \multirow{2}{*}{$\begin{array}{l}\text { Sinurat et al., } \\
2007\end{array}$} \\
\hline & & & 25 & 83,7 & - & 113,5 & 57,9 & 2,4 & \\
\hline \multirow[t]{2}{*}{$\begin{array}{l}\text { Menir } \\
\text { beras }\end{array}$} & \multirow[t]{2}{*}{48} & \multirow{2}{*}{$\begin{array}{c}\text { Commercial } \\
\text { layers } \\
\text { (Sonia) }\end{array}$} & kontrol & 90,1 & 55,6 & 106,7 & - & - & \multirow[t]{2}{*}{$\begin{array}{l}\text { Sittiya et al., } \\
2014\end{array}$} \\
\hline & & & 100 & 90,2 & 56,5 & 105,8 & - & - & \\
\hline
\end{tabular}

Keterangan: Umur (minggu), HDP (hen day production, \%), MT (masa telur, g/ekor/hari), Kon (konsumsi, g/ekor/hari), BT (berat telur, g/butir), FCR (feed conversi rasio),

indikator produktifitas ayam pedaging finisher. Tepung gaplek dan onggok merupakan produk olahan ketela pohon, sehingga kedua bahan baku tersebut mempunyai kendala yang hampir sama bila digunakan untuk subtitusi jagung. Kendala utama dari tepung gaplek dan onggok adalah kandungan $\mathrm{HCN}$ nya tinggi yaitu masig-masing $40-80 \mathrm{mg} / \mathrm{kg}$ dan $175 \mathrm{mg} / \mathrm{Kg}$ (Ariani et al., 2017; Afrian et al., 2014). HCN adalah zat antinutrisi yang sifatnya beracun apabila dikonsumsi oleh ternak dan toleransi pada ternak adalah $0,5-$ $3,5 \mathrm{mg} / \mathrm{Kg}$ berat badan (Afrian et al., 2014). Kendala lain penggunaan onggok dan tepung gaplek adalah serat kasar tinggi dan bersifat bulky (densitas rendah). Densitas bahan pakan dapat dikurangi dengan dibuat pellet atau crumbel (Ismail et al., 2016). Bozkurt et al. (2019) menambahkan bentuk pakan tepung dan crembel dapat mempengaruhi berat organ pencernaan serta performan unggas (PBB, konsumsi, FCR).
Hasil penelitain Bhuiyan and $\mathrm{Iji}$, (2015) melaporkan bahwa tepung gaplek dapat menggantikan jagung 100\% dengan perlakuan dibuat pelet dan penambahan enzim (xylanase, amylase, protease, phytase) pada ayam pedaging dengan indikator bobot badan akhir, konsumsi kumulatif, FCR dan pertambahan bobot badan harian. Onggok selain HCN juga mempunyai kendala NDF dan ADF tinggi mencapai 39,67 dan 16,57\% (Edi, 2010), sehingga dapat menggantikan jagung pada ayam petelur maksimal $50 \%$ dan $20-30 \%$ pada ayam pedaging dengan dilakukan fermentasi terlebih dahulu (Tabel 6 dan Tabel 7). Penggunaan tepung gaplek dan onggok pada ayam petelur mempunyai kendala terhadap warna kunig telur lebih pudar (tidak kuning). Hal ini terjadi karena dalam onggok maupun tepung gaplek tidak mengandung xantofil.

Bungkil sawit dapat menggantikan jagung dengan indikator produktifitas ayam 
Tabel 6. Pengaruh subtitusi jagung dengan bahan baku alternatif terhadap kualitas telur ayam petelur

\begin{tabular}{|c|c|c|c|c|c|c|c|}
\hline $\begin{array}{l}\text { Bahan pakan } \\
\text { alternatif }\end{array}$ & Umur & Strain & Subtitusi & WKT & $\mathrm{HU}$ & TK & Sumber \\
\hline \multirow[t]{2}{*}{ Jewawut } & 31 & Harco line & kontrol & 8,2 & - & - & Issa et al., 2016 \\
\hline & & & 50 & 8,0 & - & - & \\
\hline \multirow[t]{2}{*}{ Gaplek } & 44 & Isa Brown & Kontrol & 8,2 & 85,1 & - & Mampioper et al., 2008 \\
\hline & & & 45 & 4,2 & 88,4 & - & \\
\hline \multirow{2}{*}{$\begin{array}{l}\text { Tepung } \\
\text { kentang }\end{array}$} & 30 & - & Kontrol & 8,2 & 89,7 & 0,38 & Sultana et al., 2016 \\
\hline & & - & 30 & 8,5 & 88,7 & 0,37 & \\
\hline \multirow[t]{2}{*}{ Onggok } & 22 & Harco & Kontrol & 3,6 & 86,5 & 0,34 & Oladunjoye et al., 2010 \\
\hline & & & 50 & 2,5 & 84,2 & 0,33 & \\
\hline \multirow[t]{2}{*}{$\begin{array}{l}\text { Bungkil } \\
\text { sawit }\end{array}$} & 40 & $\begin{array}{c}\text { Lohman } \\
\text { Brown }\end{array}$ & Kontrol & 2,0 & 91,0 & 0,40 & Zanu et al., 2012 \\
\hline & & & 10 & 4,7 & 94,3 & 0,40 & \\
\hline \multirow[t]{2}{*}{ SHP } & 17 & Isa Brown & Kontrol & 5,4 & 99,8 & 0,45 & Sinurat et al., 2007 \\
\hline & 17 & & 25 & 5,8 & 101,0 & 0,42 & \\
\hline \multirow[t]{2}{*}{ Menir beras } & 23 & Commercial & Kontrol & 7,3 & 88,9 & 0,37 & Sittiya et al., 2014 \\
\hline & & layers (Sonia) & 100 & 5,6 & 86,9 & 0,36 & \\
\hline
\end{tabular}

Keterangan: Umur (minggu), WKT (warna kuning telur), HU (haugh unit), TK (tebal kerabang, mm)

petelur hingga 10\% tanpa perlakuan dan SHP hingga $25 \%$ dengan perlakuan fermentasi. Faktor pembatas penggunaan bungkil sawit dan SHP menggantikan jagung adalah NSP dan serat kasar tinggi karena keduanya merupakan produk olahan dari biji pohon sawit. Kandunga NDF dan ADF bungkil sawit mencapai 72,42 dan 23,30\% (Edi, 2010). NSP pada SHP dan bungkil sawit dapat dikurangi dengan cara fermentasi dan pemberian enzim (Sinurat et al., 2007; Edi, 2010).

Tepung kentang merupakan bahan baku yang bila digunakan akan berkompetisi pemanfaatannya dengan pangan. Tepung kentang dapat mensubtitusikan jagung hingga $30 \%$ pada ayam petelur dengan indikator produksi dan kualitas telur. Faktor pembatas dalam penggunaan tepung kentang adalah harganya lebih mahal dari pada jagung. Kendala ini dapat dikurangi dengan memanfaatkan kentang afkir yang tidak layak untuk pangan.

Menir beras pada ayam petelur dapat menggantikan jagung hingga $100 \%$ dengan indikator produksi telur dan kualitas telur (Tabel 5 dan Tabel 6) dan 75\% pada angsa pedaging (Tabel 7) dengan performan lebih baik. Masalah yang timbul penggunaan menir beras untuk menggantikan jagung adalah warna kuning telur lebih pudar karena dalam menir beras tidak terdapat xantofil seperti pada jagung (Jadhao et al., 2000). Kandungan Permasalahan ini dapat dikurangi dengan penambahan xantofil sintetis pada formulasi pakan. Pigmen kuning (xantofil) pada jagung diantaranya adalah lutein 0,88 41,85 , Zeaxanthin $0,74-30,68$ dan $\beta$-carotene $0,05-16,79 \mu \mathrm{g} / \mathrm{g}$ bahan kering (Muzhingi et al., 2007).

Pemanfaatan produk afkir berupa mie afkir dan roti afkir dapat menggantikan jagung masing-masing hingga 20 dan $100 \%$. Pemanfaatan mie afkir hingga $20 \%$ dari jagung dapat dilakukan pada ayam pedaging dengan indikator berat hidup sama dengan penggunaan jagung (Widodo et al., 2010). Pemanfaatan tepung roti afkir hingga $100 \%$ untuk subtitusi jagung pada itik bali dapat 
JPI Vol. 23 (1): 43-61

Tabel 7. Pengaruh subtitusi jagung dengan bahan baku alternatif terhadap produktifitas unggas pedaging

\begin{tabular}{|c|c|c|c|c|c|c|c|c|}
\hline $\begin{array}{l}\text { Bahan } \\
\text { pakan } \\
\text { alternatif }\end{array}$ & $\begin{array}{l}\text { Strain/ } \\
\text { Jenis } \\
\text { unggas }\end{array}$ & Umur & $\begin{array}{l}\text { Subtitusi dan } \\
\text { perlakuan }\end{array}$ & LB & PBB & FCR & Kon & Sumber \\
\hline \multirow[t]{2}{*}{ Sorgum } & \multirow[t]{2}{*}{ Cobb 500} & \multirow[t]{2}{*}{$0-21$} & kontrol & 527,5 & 26,4 & 1,76 & 287,0 & \multirow[t]{2}{*}{$\begin{array}{l}\text { Tandiang et al., } \\
2014\end{array}$} \\
\hline & & & $\begin{array}{l}100 \\
\text { Sorgum low tanin } \\
\text { (Sorghum bicolor } \\
\text { cultivar Faourou) }\end{array}$ & 597,3 & 28,5 & 1,8 & 314,4 & \\
\hline \multirow[t]{2}{*}{ Sorgum } & \multirow[t]{2}{*}{ Cobb 500} & \multirow[t]{2}{*}{$22-43$} & kontrol & 1303 & 48,4 & 2,79 & 810,5 & \multirow[t]{2}{*}{$\begin{array}{l}\text { Tandiang et al., } \\
2014\end{array}$} \\
\hline & & & $\begin{array}{l}100 \\
\text { Sorgum low tanin } \\
\text { (Sorghum bicolor } \\
\text { cultivar Faourou) }\end{array}$ & 1418 & 47,0 & 2,79 & 786,2 & \\
\hline \multirow[t]{2}{*}{ Gandum } & \multirow[t]{2}{*}{ Cobb } & \multirow[t]{2}{*}{$0-42$} & kontrol & 2084 & 48,7 & 1,3 & 2805 & \multirow[t]{2}{*}{$\begin{array}{l}\text { ElKatcha et al., } \\
2014\end{array}$} \\
\hline & & & $\begin{array}{c}50 \\
\text { (Penambahan } \\
\text { enzim } 200 \mathrm{~g} / \text { ton } \\
\text { (enzim amilase dan } \\
\text { protease) }\end{array}$ & 2030 & 47,4 & 1,4 & 2867 & \\
\hline \multirow[t]{2}{*}{ Jewawut } & \multirow[t]{2}{*}{ Ross 308} & \multirow[t]{2}{*}{$8-21$} & kontrol & 560 & - & 1,2 & 1113 & \multirow{2}{*}{$\begin{array}{l}\text { Goodarzi } \\
\text { Boroojeni et al., } \\
2011\end{array}$} \\
\hline & & & 100 & 598 & - & 1,2 & 1134 & \\
\hline \multirow[t]{2}{*}{ Jewawut } & \multirow[t]{2}{*}{ Ross 308} & \multirow[t]{2}{*}{$22-42$} & kontrol & 1655 & - & 1,6 & 1617 & \multirow{2}{*}{$\begin{array}{l}\text { Goodarzi } \\
\text { Boroojeni et al., } \\
2011\end{array}$} \\
\hline & & & 100 & 1897 & - & 1,5 & 1743 & \\
\hline \multirow{2}{*}{$\begin{array}{l}\text { Tepung } \\
\text { kentang }\end{array}$} & \multirow[t]{2}{*}{ Ross 308} & \multirow[t]{2}{*}{$22-42$} & kontrol & 2148 & - & 1,9 & 2966 & \multirow[t]{2}{*}{ Adami et al., 2017} \\
\hline & & & 40 & 2176 & - & 2,0 & 2998 & \\
\hline \multirow[t]{2}{*}{ Gaplek } & \multirow[t]{2}{*}{ Cobb 500} & \multirow[t]{2}{*}{$0-21$} & kontrol & 696,1 & 75,9 & 1,4 & 948 & \multirow[t]{2}{*}{$\begin{array}{l}\text { Bhuiyan and } \mathrm{Iji} \text {, } \\
2015\end{array}$} \\
\hline & & & $\begin{array}{c}100 \\
\text { (pelet dan } \\
\text { penambahan enzim } \\
\text { xylanase, amylase, } \\
\text { protease, phytase) }\end{array}$ & 749,4 & 74,6 & 1,6 & 1162 & \\
\hline \multirow[t]{3}{*}{ Onggok } & \multirow[t]{3}{*}{ Hubbard } & \multirow[t]{3}{*}{$0-35$} & kontrol & 1510 & 43,2 & 2,1 & 3158 & \multirow[t]{3}{*}{$\begin{array}{l}\text { Ali-Mursyid et al., } \\
2010\end{array}$} \\
\hline & & & 20 & 1591 & 45,5 & 2,1 & 3322 & \\
\hline & & & 30 (Fermentasi) & 1549 & 44,3 & 2,1 & 3331 & \\
\hline \multirow{2}{*}{$\begin{array}{l}\text { Kulit } \\
\text { pisang }\end{array}$} & \multirow{2}{*}{$\begin{array}{l}\text { Arbor } \\
\text { Acres }\end{array}$} & $0-28$ & Kontrol & 1997 & 50,6 & 1,9 & 3956 & Fas et al., 2015 \\
\hline & & & 10 (Tepung) & 1933 & 48,3 & 2,0 & 3939 & \\
\hline $\begin{array}{l}\text { Mie } \\
\text { afkir }\end{array}$ & Lohman & $0-35$ & Kontrol & 1464 & - & - & - & $\begin{array}{l}\text { Widodo et al., } \\
2010\end{array}$ \\
\hline
\end{tabular}


JPI Vol. 23 (1): 43-61

\begin{tabular}{|c|c|c|c|c|c|c|c|c|}
\hline $\begin{array}{l}\text { Bahan } \\
\text { pakan } \\
\text { alternatif }\end{array}$ & $\begin{array}{c}\text { Strain/ } \\
\text { Jenis } \\
\text { unggas }\end{array}$ & Umur & $\begin{array}{l}\text { Subtitusi dan } \\
\text { perlakuan }\end{array}$ & LB & PBB & FCR & Kon & Sumber \\
\hline \multirow{3}{*}{$\begin{array}{l}\text { Roti } \\
\text { afkir }\end{array}$} & \multirow{3}{*}{ Itik bali } & \multirow{3}{*}{$2-8$} & 20 & 1491 & - & - & - & \multirow{3}{*}{$\begin{array}{l}\text { Trisnadewi et al., } \\
2012\end{array}$} \\
\hline & & & kontrol & 1106 & 20,3 & 7,3 & 6218 & \\
\hline & & & $\begin{array}{c}100 \\
\text { (Penambahan tepung } \\
\text { jerami bawang putih } \\
20 \% \text { ) }\end{array}$ & 1245 & 23,6 & 6,8 & 6742 & \\
\hline \multirow{2}{*}{$\begin{array}{l}\text { Menir } \\
\text { beras }\end{array}$} & \multirow[t]{2}{*}{ Angsa } & \multirow[t]{2}{*}{$28-42$} & kontrol & 1205 & 86,1 & 2,5 & 3080 & \multirow[t]{2}{*}{ Chen et al., 2020} \\
\hline & & & 100 & 1226 & 87,6 & 2,3 & 2870 & \\
\hline
\end{tabular}

Keterangan: LB (bobot hidup, g/ekor), PBB (pertambahan bobot badan harian, g/ekor/hari), Kon (konsumsi kumulatif, g/ekor), FCR (feed conversion rasio)

terjadi karena diberi fitobiotik berupa tepung jerami bawang putih hingga $20 \%$ dari roti afkir (Trisnadewi et al., 2012).

\section{KESIMPULAN}

Bahan pakan alternatif sumber energi untuk subtitusijagung pada unggas diantaranya adalah sorgum, gandum, jewawut, gaplek dan kentang, onggok, bungkil sawit, kulit pisang, solid heavy phase (SHP), menir beras, mie afkir dan roti afkir. Beberapa hal yang perlu diperhatikan dalam penggunaannya adalah batasan penggunaan, jenis dan umur unggas, antinutrisi serta keseimbangan nutrien utama seperti energi metabolis, protein kasar, asam amino pembatas, kalsium, fosfor dan densitas pakan. Penggunaan bahan baku pakan alternatif yang tepat dapat menekan harga pakan, kebutuhan nutrien ternak terutama energi metabolis tetap terpenuhi dan produktifitas ternak tetap optimal sehingga dapat meningkatkan profitabiltas peternak.

\section{DAFTAR PUSTAKA}

Adami, S., Sadeghi, G., Karimi, A., Azizi, O., Habibian, M. 2017. Effects of replacement of corn with potato (Solanum tuberosum L.) tuber meal in broiler chicken diets. Animal Production Science, 57(2), 320.

Adedokun, S. A., and Adeola, O. 2013. Calcium and phosphorus digestibility: Metabolic limits. Journal of Applied Poultry Research, 22(3), 600-608.

Afrian, F. A., Liman, Ys, S. T. 2014. Survei Populasi kapang dan kadar HCN pada onggok dengan proses pengeringan yang berbeda di propinsi lampung.

Ali-Mursyid, W. M., Bachruddin, Z., Zuprizal, Z., Nur-Cahyanto, M. 2010. Corn substitution using fermented solid cassava-waste on broiler chicken. Journal of the Indonesian Tropical Animal Agriculture, 35(1), 9-15.

Almrsomi, T. S., AlShukri, A. Y., Areaaer, A. H. 2019. The Effect Of Substitution Broken Rice (Oryza Sativa) For The Yellow Corn (Zea Mays) On The Performance Of Broiler Ross 308. Plant Archives 19 (1) : 279-283

Alshelmani, M. I., Loh, T. C., Foo, H. L., Sazili, A. Q., Lau, W. H. 2016. Effect of feeding different levels of palm kernel cake fermented by Paenibacillus polymyxa ATCC 842 on nutrient digestibility, intestinal morphology, and gut microflora in broiler chickens. Animal Feed Science and Technology, 216, 216-224. 
Anaeto, M., and Adighibe, L. 2011. Cassava root meal as substitute for maize in layers ration. Revista Brasileira de Ciência Avícola, 13(2), 153-156.

Anderemi, F. A., Adenowo, T. K., Oguntunji, A. O. 2012. Effect of Whole Cassava Meal on Performance and Egg Quality Characteristics of Layers. Journal of Agricultural Science. 4(2) : 195-200

Ashour, E. A., Reda, F. M., Abd El-Hack, M. E. 2016. The Influences of Partially Replacement of Maize Corn by Broken Rice and Sugar Beat Pulp on Growth Performance, Carcass Traits and Economics of Meat-Type Quails. Iranian Journal of Applied Animal Science 6(3), 715-722

Astuti, E. 2009. Karakterisasi Tepung Beras Menir Pragelatinisasi Dan Perubahan Mutunya Selama Penyimpanan. Skripsi. Departemen Teknologi Industri Pertanian. Fakultas Teknologi Pertanian. Institut Pertanian Bogor. Bogor

Aqsa, A. D., Kiramang, K., Hidayat, M. N. 2016. Profil Organ Dalam Ayam Pedaging (Broiler) Yang Diberi Tepung Daun Sirih (Piper Betle Linn) Sebagai Imbuhan Pakan. Jurnal Ilmu dan Industri Perternakan, 3 (1) : 148-159

Ariani, L., Estiasih, T., Martati, E. 2017. Physicochemical Characteristic Of Cassava (Manihot utilisima) with Different Cyanide Level. Jurnal Teknologi Pertanian, 18(2), 119-128. https://doi.org/10.21776/ ub.jtp.2017.018.02.12

Aro, S. O., and Aletor, V. A. 2012. Proximate composition and amino acid profile of differently fermented cassava tuber wastes collected from a cassava starch producing factory in Nigeria. Livestock Research for Rural Development 24 (3)

Atapattu, N.S.B.M and Senevirathne, T.S.M.S. 2012. Effects of Increasing Levels of Dietary Cooked and Uncooked Banana Meal on Growth Performance and
Carcass Parameters of Broiler Chicken. Pakistan Veterinary Journal, 33(2) : 179-182

Attia, Y. A., Aggoor, F. A. M., Ismail, F. S. A., Qota, E. M. A., Shakmak, E. A. 2006. Effect of energy level, rice by products and enzyme additions on growth performance and energy utilization of Japanese quail. EPC 2006 XII European Poultry Conference, Verona, Italy 1014 Sepetmeber, 2006

Babatunde, B. B. 2013. Effect of Feeding Cassava Wastes on the Performance and Meat Quality of Broiler Chickens. Mal. J. Anim. Sci. 16(2):63-73

Bangun, G. D. D., Mahfuds, L. D., Sunarti, D. 2013. Pengaruh penggunaan tepung rumput laut (Gracilaria verrucosa) dalam ransum ayam broiler terhadap berat dan ukuran tulang tibia dan tarsometatarsus. Animal Agriculture Journal, 2(1), 489-496.

Bhuiyan, M. M., \& Iji, P. A. 2015. Energy Value of Cassava Products in Broiler Chicken Diets with or without Enzyme Supplementation. Asian-Australasian Journal of Animal Sciences, 28(9), 1317-1326.

Bozkurt, M., Kocer, B., Ege, G., Tuzun, A. E., Biyik, H. H., Poyrazo glu, E. 2019. Influence of the particle size and form of feed on growth performance, digestive tract traits and nutrient digestibility of white egg-laying pullets from 1 to 112 D of age. Poultry Science 98 : 40164029

Bulu, S., Rejeki, I. G. A. S., Mardewi, N. K. 2018. Pemakaian sorgum (Sorghum bicolor 1.) sebagai bahan substitusi jagung (Zea mays 1.) pada ransum terhadap berat bagian bagian karkas ayam broiler umur 6 minggu. Gema Agro, 23(2) : 124-128

Charrondiere, U. R., Haytowitz, D., Stadlmayr, B. 2015. Density Database version 2. FAO/INFOODS

Chen, X., Yang, H., Xu, L., Wan, X., Wang, 
Z. 2020. Effect of replacing dietary corn with broken rice on goose growth performance, body size and bare skin color. Animals, 10(8) : 1-10

Chong, C. H., Zulkifli, I., Blair, R. 2008. Effects of Dietary Inclusion of Palm Kernel Cake and Palm Oil, and Enzyme Supplementation on Performance of Laying Hens. Asian-Australasian Journal of Animal Sciences, 21(7), 1053-1058.

Cisse, R. S., Hamburg, J. D., Freeman, M. E., Davis, A. J. 2017. Using locally produced millet as a feed ingredient for poultry production in Sub-Saharan Africa. Journal of Applied Poultry Research, 26(1), 9-22.

Dadalt, J. C., Gallardo, C., Polycarpo, G. V., Budiño, F. E. L., Rogiewicz, A., Berto, D. A., Trindade Neto, M. A. 2016. Ileal Amino Acid Digestibility of Broken Rice Fed to Postweaned Piglets with or without Multicarbohydrase and Phytase Supplementation. Asian-Australasian Journal of Animal Sciences, 29(10), 1483-1489.

Diarra, S. S., and Devi, A. 2015. Feeding Value of Some Cassava By-Products Meal for Poultry: A Review. Pakistan Journal of Nutrition, 14(10), 735-741.

Edi, D. N. 2010. Evaluasi Nilai Nutrisi Campuran Bungkil Inti Sawit dan Onggok yang Difermentasi Dengan Mix Culture Microbes Sebagai Bahan Pakan Unggas. Skripsi. Jurusan Nutrisi dan Makanan Ternak. Fakultas Peternakan Universitas Brawijaya. Malang

ElKatcha, M., Soltan, M., ElKanwy, H., kawarie, El. 2014. Growth Performance, Blood Parameters, Immune response and Carcass Traits of Broiler Chicks Fed on Graded Levels of Wheat Instead of Corn without or With Enzyme Supplementation. Alexandria Journal of Veterinary Sciences, 40(1), 95.

Fas, A., Oa, A., Ob, O., Oo, O., Oy, A.-A., Jo, A. 2015. Effects of Treated Banana
Peel Meal on the Feed Efficiency, Digestibility and Cost Effectiveness of Broiler Chickens Diet. Journal of Veterinary Science and Animal Husbandry, 1(6).

Filgueira, T., Freitas, E., Quevedo Filho, I., Fernandes, D., Watanabe, P., Oliveira, A. de. 2014. Corn replacement by broken rice in meat-type quail diets. Revista Brasileira de Ciência Avícola, 16(4), 345-350

Fitroh, B. A., Wihandoyo, W., Supadmo, S. 2018. The Use 3 of Banana Peel Meal (Musa paradisiaca) as Substitution of Corn in the Diets on Performance and Carcass Production of Hybrid Ducks. Buletin Peternakan, 42(3).

Goodarzi Boroojeni, F., Samie, A. H., Edriss, M. A., Khorvash, M., Sadeghi, G., Van Kessel, A., Zentek, J. 2011. Replacement of corn in the diet of broiler chickens using foxtail millet produced by 2 different cultivation strategies. Poultry Science, 90(12), 2817-2827

Hartadi, H. 1980. Tabel-Tabel Dari Komposisi Bahan Makanan Ternak Untuk Indonesia, Data Ilmu Makanan Untuk Indonesia. Fakultas Peternakan. Universitas Gadjah Mada. Yogyakarta

Has, H., Napirah, A., dan Indi, A. 2014. Efek peningkatan serat kasar dengan penggunaan daun murbei dalam ransum broiler terhadap persentase bobot saluran pencernaan. JITRO, 1(1) : 63-69

Hudiansyah, P., Sunarti, D., Sukamto, B. 2015. Pengaruh Penggunaan Kulit Pisang Terfermentasi Dalam Ransum Terhadap Ketersediaan Energi Ayam Broiler. AROMEDIA, 33(2), 1-9

Hur, On-Sook, Chang, Dong Chil, Kim, Sun Lim, Ok, Hyun-Choong, Kim, Jung-Tae, and Chun, Changhoo. 2011. Sugar, Amino Acid and Fatty Acid Composition in Potato Tubers Grown in Highland Area of Gangwon Province, 
24(6), 688-695.

Hy-Line Brown. 2014. Panduan Manajemen : Ayam Petelur Komersial Hy-Line Brown. Hy-Line International EggCel. www.hylineeggcel.comS

Ismail, F., Sherif, Kh., EL-Gogary, M., Tuama, S. 2016. Effect of nutrient density and feed form on productive performance and blood parameters of broiler chickens. Journal of Animal and Poultry Production, 7(3), 121-128.

Issa, S. 2009. Nutritional Value Of Sorghum For Poultry Feed In West Africa. Disertasi. Department of Animal Sciences and Industry College of Agriculture. Kansas State University. Manhattan, Kansas

Issa, S., Jarial, S., Brah, N., Harouna, L. 2016. Are millet and sorghum good alternatives to maize in layer's feeds in Niger, West Africa?. Indian Journal of Animal Sciences, 86 (11): 1302-1305

Jadhao, S. B., Tiwarp, C. M., Khan, M. Y. 2000. Effect of complete replacement of maize by broken rice in the diet of laying hens. Indian J. Anim. Nutr., 17 (3) : 237-242

Jafarnejad, S., Farkhoy, M., Sadegh, M., Bahonar, A. R. 2010. Effect of CrumblePellet and Mash Diets with Different Levels of Dietary Protein and Energy on the Performance of Broilers at the End of the Third Week. Veterinary Medicine International, 2010, 1-5

Jayanegara, A., Ridla, M., Laconi, E. B., Nahrowi. 2019. Komponen Antinutrisi Pada Pakan. IPB Press, Bogor

Kasapidou, E., Sossidou, E., Mitlianga, P. 2015. Fruit and Vegetable Co-Products as Functional Feed Ingredients in Farm Animal Nutrition for Improved Product Quality. Agriculture, 5(4), 1020-1034

Kaul, J., Jain, K., Olakh, D. 2019. An Overview on Role of Yellow Maize in Food, Feed and Nutrition Security. International Journal of Current Microbiology and
Applied Sciences, 8(02), 3037-3048

Kierończyk, B., Rawski, M., Długosz, J., Świątkiewicz, S., Józefiak, D. 2016. Avian Crop Function - A Review. Annals of Animal Science, 16(3), 653678

Kiramang, K. 2011. Potensi dan pemanfaatan onggok dalam ransum unggas. Jurnal Teknosains, 5(2) : 155-163

Kumar, P., Yadava, R., Gollen, B., Kumar, S., Verma, R., Yadav, S. 2011. Nutritional Contents and Medicinal Properties of Wheat: A Review. Life Sciences and Medicine Research, $22: 1-10$

Kumaravel, V. and Natarajan, A. 2015. Nutritive Value Of Pearl Millet Grains For Poultry Feed-A Review. International Journal of Science, Environment and Technology, 4 (1) : 230-233

Kusmayadi, A. 2019. Pengaruh Kombinasi Tepung Roti Afkir Dan Tepung Kulit Manggis Sebagai Substitusi Jagung Dalam Ransum Itik Cihateup Terhadap Performan Pertumbuhan Dan Income Over Feed Cost. Jurnal Peternakan, 16(2), 43

Mampioper, A., Rumetor, S. D., Pattiselanno, F. 2008. Kualitas Telur Ayam Petelur Yang Mendapat Ransum Perlakuan Substitusi Jagung Dengan Tepung Singkong. J. Ternak Tropika, 9 (2) : 4251

Marsono, Y dan Astanu, W. P. 2002. Pengkayaan Protein Mie Instan dengan Tepung Tahu. Agritech, 22(3) : 99-103

Medugu, C. I., Kwari, I. D., Igwebuike, J., Nkama, I., Mohammed, I. D., Hamaker, B. (2010). Performance and economics of production of broiler chickens fed sorghum or millet as replacement for maize in the semi-arid zone of Nigeria. Agriculture and Biology Journal of North America, 1(3), 321325.

Mir, N. A., Tyagi, P. K., Biswas, A. K., Tyagi, 
P. K., Mandal, A. B., Kumar, F., Deo, C., Biswas, A. 2015. Effect of feeding broken rice and distillers dried grains with solubles in a flaxseed-based diet on the growth performance, production efficiency, carcass characteristics, sensory evaluation of meat, and serum biochemistry of broiler chickens. Turk $J$ Vet Anim Sci, 41 : 583-589

Musita, N. 2018. Kajian Sifat Fisikokimia Tepung Onggok Industri Besar Dan Industri Kecil. Majalah TEGI, 10(1) : 19-24

Muzhingi, T., Yeum, K., Russell, R. M., Johnson, E. J., Qin, J., Tang, G. 2007. Determination of carotenoids in yellow maize, the effects of saponification and food preparations. Int. J. Vitam. Nutr. Res., 78 (3) : 112-120

Nafiah, Y. I. 2009. Kajian Fisik-Kimia Jagung (Zea mays) Pipilan Pasca Proses Pengeringan dan fermentasi dengan Penambahan Asam Propionat dan Molases Selamat Penyimpanan. Tesis. Sekolah Pasca Sarjana. Institut Pertanian Bogor. Bogor

Natsir, M. H., Djunaidi, I., Sjofjan, O., Suwanto, A., Puspitasari, E., Virginia, L. J. 2018. The Effect of Corn Substitution with Palm Kernel Meal Treated by Enzyme on Production Performance and Carcass Quality of Broiler. Bulletin of Animal Science, 42(2) : 103-108

Nopriani, D. 2006. Pengaruh Substitusi Jagung dengan Sorgum dan Menir Sebagai Sumber Pati Terhadap Kualitas Fisik Pelet Pakan Broiler Finisher. Skripsi. Program Studi Nutrisi dan Makanan Ternak. Fakultas Peternakan Institut Pertanian Bogor. Bogor

Octavia, S., Djunaidi, I. H., dan Widodo, E. 2018. Kandungan Energi Metabolis Semu Pakan Dan Energi Metabolis Semu Terkoreksi N Pada Gandum Dengan Suplementasi Enzim Sebagai Substitusi Jagung. Jurnal Ilmiah Peternakan Terpadu, 5(3), 68-71
Okereke, C. O. 2011. Utilization of Cassava, Sweet Potato, and Cocoyam Meals as Dietary Sources for Poultry. World J of Engineering and Pure and Applied Sci., $2(3): 63-68$

Oladunjoye, I.O., Ojebiyi, O., Amao, O.A., 2010. Ffect Of Feeding Processed Cassava (Manihot esculenta Crantz) Peel Meal Based Diet On The Performance Characteristics, Egg Quality And Blood Profile Of Laying Chicken. Agricultura Tropica Et Subtropica. 43(2) : 119-126

Onunkwo, D. N., Ugwuene, M. C., Eze, J. C. R. and Okpechi, F. C.2018. Replacement Value Of Palm Kernel Meal For Maize On Growth, Egg Quality, And Economic Parameters Of Local Duck Hens. Nigerian J. Anim. Sci., 20 (1): 145-151

Panikkai, S., Nurmalina, R., Mulatsih, S., Purwati, H. 2017. Analysis of National Corn Availability to Become Selfsufficiency Throught Dynamic Model Approachmen. Informatika Pertanian, 26 (1) : 41-48

Pusat Data dan Sistem Informasi Pertanian Kementan RI. 2018. Outlook Jagung : Komoditas Pertanian Subsektor Tanaman Pangan. Pusat Data dan Sistem Informasi Pertanian Kementrian Pertanian Republik Indonesia

Putra, G. Y., dan Sudarwati, H. 2019. Pengaruh penambahan fermentasi kulit pisang kepok (Musa paradisiaca L.) pada pakan lengkap terhadap kandungan nutrisi dan kecernaan secara in vitro. Jurnal Nutrisi Ternak Tropis, 2 (1) : 4252

Rahmawati. 2016. Histologis Saluran Pencernaan Ayam Buras Hasil In Ovo Feeding Asam Amino L-Arginine. Skripsi. Progrma Studi Peternakan. Fakultas Peternakan. Universitas Hasanudin. Makasar

Ribeiro J., V., Salguero, S.C., Vieira, R.A., Silva, L.M., Silva, D.L.,Hannas, M.I., 
Albino, L.F.T. and Rostagno, H.S. 2016. Crude protein levels in diets for laying hens. Arch. Zootec. 65 (250 ): 225-229

Samadi, S. 2012. Konsep Ideal Protein (Asam amino) Fokus Pada Ternak Ayam Pedaging (review artikel). Jurnal Agripet, 12(2), 42-28

Scott, M. P., Edwards, J. W., Bell, C. P., Schussler, J. R., Smith, J. S. 2006. Grain Composition And Amino Acid Content In Maize Cultivars Representing 80 Years Of Commercial Maize Varieties. Maydica, $51: 417-423$

Setiarto, R. H. B dan Widhyastuti, N. 2016. Reduction of Tannin and Phytic Acid on Sorghum Flour by using Fermentation of Rhizopus oligosporus, Lactobacillus plantarum and Saccharomyces cerevisiae. Berita Biologi, 15 (2) : 149157

Shakila, S., Reddy, P. S., Reddy, P.V.V.S., Ramana, J. V., Ravi, A. 2012. Effect of palm kernel meal on the performance of broilers. Tamilnadu J. Veterinary \& Animal Sciences 8 (4) 227-234

Singh, D. 2004. Evaluation of new millet varieties as a poultry feed ingredient. Rural Industries Research and Development Corporation (Australia), Rural Industries Research and Development Corporation, \& Chicken Meat Research and Development (Program). RIRDC

Sinurat, A. P., Purwadaria, T., Bintang I. A. K., Pasaribu, T. 2007. Peningkatan Nilai Gizi Solid heavy phase dalam Ransum Unggas sebagai Pengganti Jagung. JITV, 12(2) : 87-95

Sittiya, J., Yamauchi, K., Takata, K. 2014. Effects of Replacing Corn with WholeGrain Paddy Rice in Laying Hen Diets on Egg Production Performance. Journal of Advanced Agricultural Technologies, 1(1), 1-4.

Sriagtula, R., Djulardi, A., Yuniza, A. 2019.
Effects of the Substitution of Corn with Sorghum and the Addition of Indigofera Leaf Flour on the Performance of Laying Hens. Advances in Animal and Veterinary Sciences, 7(10) : 829-834

Sukarman, S. 2011. Berbagai alternatif bahan baku lokal untuk pakan ikan. Media Akuakultur, 6(1) : 36-42

Sultana, F., Khatun, H., Ali, M. A. 2016. Use of potato as carbohydrate source in poultry ration. Chemical and Biological Technologies in Agriculture, 3(30) : 1-7

Sundu, B., Kumar, A., Dingle, J. 2006. Palm kernel meal in broiler diets: Effect on chicken performance and health. World's Poultry Science Journal, 62(2), 316-325

Tandiang, D. M., Diop, M. T., Dieng, A., Yoda, G. M. L., Cisse, N., Nassim, M. 2014. Effect of Corn Substitution by Sorghum Grain with Low Tannin Content on Broilers Production: Animal Performance, Nutrient Digestibility and Carcass Characteristics. International Journal of Poultry Science, 13(10), 568-574. https://doi.org/10.3923/ ijps.2014.568.574

Teme, A. B. Y., Selan, Y. N., Amalo, F. A. 2019. Gambaran anatomi dan histologi oesofagus dan proventrikulus pada ayam hutan merah (Gallus gallus) asal Pulau Timor. Jurnal Veteriner Nusantara. 2(2) : 85-103

Trisnadewi, A. A. A. S., Utami, I. A. P., Aryani, I. G. A. I., Partama, I. B. G., Bidura, I. G. N. G. 2012. Pengaruh Penggantian Penggunaan Jagung Kuning Dalam Ransum Dengan Campuran Limbah Roti Dan Tepung Jerami Bawang Putih Terhadap Penampilan Dan Jumlah Lemak Abdomen Itik Bali Jantan. Majalah Ilmiah Peternakan, 15 (1) : 6-10

Weurding, R. E., Veldman, A., Veen, W. A. G., van der Aar, P. J., Verstegen, M. W. A. 2001. Starch Digestion Rate in the Small Intestine of Broiler Chickens 
Differs among Feedstuffs. The Journal of Nutrition, 131(9), 2329-2335.

Widodo, E., Sjofjan, O., Wijaya, A. Z. 2010. Limbah mie sebagai pengganti jagung dalam pakan ayam pedaging dan pengaruhnya terhadap kualitas karkas. Jurnal Ilmu dan Teknologi Hasil Ternak, 5(1) : 38-44

Zanu, H. K., Abangiba, J., Arthur Badoo, W., Akparibo, A. D., Sam, R. 2012. Laying chickens response to various levels of palm kernel cake in diets. International Journal of Livestock Production, 3(1), 12-16.

Zarei, M., Ehsani, M., Torki, M. 2011. Productive performance of laying hens fed wheat-based diets included olive pulp with or without a commercial enzyme product. Afr. J. Biotechnol, 10 (20) : 4303-4312 